\title{
Operational surface UV radiation product from GOME-2 and AVHRR/3 data
}

\author{
J. Kujanpää and N. Kalakoski \\ Finnish Meteorological Institute, Earth Observation Unit, P.O. Box 503, 00101 Helsinki, Finland \\ Correspondence to: J. Kujanpää (jukka.kujanpaa@fmi.fi)
}

Received: 28 January 2015 - Published in Atmos. Meas. Tech. Discuss.: 4 May 2015

Revised: 24 September 2015 - Accepted: 28 September 2015 - Published: 21 October 2015

\begin{abstract}
The surface ultraviolet (UV) radiation product, version 1.20, generated operationally in the framework of the Satellite Application Facility on Ozone and Atmospheric Chemistry Monitoring (O3M SAF) of the European Organisation for the Exploitation of Meteorological Satellites (EUMETSAT) is described. The product is based on the total ozone column derived from the measurements of the second Global Ozone Monitoring Experiment (GOME-2) instrument aboard EUMETSAT's polar orbiting meteorological operational (Metop) satellites. Cloud cover is taken into account by retrieving cloud optical depth from the channel 1 reflectance of the third Advanced Very High-Resolution Radiometer (AVHRR/3) instrument aboard both Metop in the morning orbit and Polar Orbiting Environmental Satellites (POES) of the National Oceanic and Atmospheric Administration (NOAA) in the afternoon orbit. In addition, more overpasses are used at high latitudes where the swaths of consecutive orbits overlap. The input satellite data are received from EUMETSAT's Multicast Distribution System (EUMETCast). The surface UV product includes daily maximum dose rates and integrated daily doses with different biological weighting functions, integrated ultraviolet B (UVB) and ultraviolet A (UVA) radiation, solar noon UV index and daily maximum photolysis frequencies of ozone and nitrogen dioxide at the surface level. The quantities are computed in a $0.5^{\circ} \times 0.5^{\circ}$ regular latitude-longitude grid and stored as daily files in the hierarchical data format (HDF5) within 2 weeks from sensing. The product files are archived in the O3M SAF distributed archive and can be ordered via the EUMETSAT Data Centre.
\end{abstract}

\section{Introduction}

Sunlight covers a wide spectral range of electromagnetic radiation. Ultraviolet (UV) radiation relevant to life on Earth is in the wavelength range $280-400 \mathrm{~nm}$, below the short wavelength end of visible light. This wavelength range is further divided in ultraviolet A (UVA) $(315-400 \mathrm{~nm})$ and ultraviolet B (UVB) (280-315 nm) spectral regions. Photons in the UV range are more energetic than in visible light, and in particular the UVB radiation has enough energy to cause direct damage to the deoxyribonucleic acid (DNA) encoding the genetic information in a variety of organisms ranging from bacteria to humans (Sinha and Hader, 2002). Ozone absorbs radiation in the UVB spectral range and therefore the level of UVB radiation reaching the Earth's surface is highly sensitive to the amount of ozone in the atmosphere. Depletion of the ozone layer results in higher levels of UV radiation on the Earth's surface posing a threat to human health and ecosystems. Other main factors affecting the surface UV radiation are solar elevation, Sun-Earth distance, altitude, clouds, aerosols and surface albedo (Weatherhead et al., 2005). After the discovery of the Antarctic ozone depletion, the Vienna convention and the Montreal protocol were agreed upon requiring participating countries to conduct research on the human health and biological effects occurring from modifications of the ozone layer, and resulting in changes in ultraviolet solar radiation having biological effects. To raise public awareness of the risks of excessive exposure to UV radiation, the UV index was adopted by the World Health Organisation (WHO) as a measure of the level of UV radiation (WHO, 2002). UV radiation can also have positive impacts on health. In particular, UVB radiation prevents vitamin $\mathrm{D}$ deficiency through inducing vitamin $\mathrm{D}$ production in human skin (Holick, 2007). The lack of UVB radiation in 
the winter time increases the risk of vitamin D deficiency at high latitudes and dietary supplements are needed (LambergAllardt et al., 2001). In addition to the health effects, UV radiation catalyses important tropospheric photochemical reactions relevant to air quality (Madronich, 1993). The photodissociation of tropospheric ozone leads to the formation of hydroxyl radical, an important oxidising agent in the troposphere, while the photodissociation of nitrogen dioxide is a source of tropospheric ozone. A recent study suggests that $\mathrm{UV}$ radiation also plays an important role in photo-oxidation of dissolved organic carbon (DOC) in arctic fresh waters contributing to about one-third to the total $\mathrm{CO}_{2}$ released from surface waters (Cory et al., 2014). Finally, UV radiation plays an important role in photodegradation of polymer materials (Andrady et al., 1998).

Surface UV radiation can be measured locally with ground-based instruments, although an accurate measurement is a challenging task (Seckmeyer et al., 2001). Another challenge is the extreme diurnal cycle due to solar elevation and modulation by rapidly changing cloud fields requiring high temporal measurement resolution. Obviously, surface irradiance cannot be directly measured from space but satellite measurements can be used as input data to radiative transfer modelling, giving estimates of the surface UV radiation levels. Polar orbiting satellites can provide global coverage but have infrequent sampling of the diurnal cycle. Also the local satellite overpass time is different for different satellites and varies with geographical location. A near-noon (local time) overpass time is desirable to capture the maximum UV dose rate while at least two overpasses, one in the morning and another in the afternoon, are needed to satisfactorily approximate the cloud-modulated diurnal cycle (Meerkötter and Bugliaro, 2002; Bugliaro et al., 2006; Martin et al., 2000, and references therein). Pioneering work on satellite UV radiation products was carried out on the Total Ozone Mapping Spectrometer (TOMS) data (Krotkov et al., 1998, 2001). The TOMS instruments were aboard satellites on near-noon orbits allowing for the estimation of surface UV quantities from a single overpass. The Equator crossing time of the Nimbus-7 satellite, launched in October 1978, was originally very near local noon but drifted towards 10:40 LT over the 14.5 year of operation (McPeters and Labow, 1996). Another important TOMS-carrying satellite was the Earth Probe, launched in July 1996, with an equatorial crossing of 11:16 LT (McPeters et al., 1998). The TOMS surface UV algorithm was modified to use the measurements of the Dutch-Finnish Ozone Monitoring Instrument (OMI) aboard NASA's Aura satellite, launched in July 2004 (Tanskanen et al., 2006, 2007). Aura is an afternoon orbiter with an equatorial crossing time of 13:45 LT (Schoeberl et al., 2006). Contrary to polar orbiters, geostationary satellites provide better temporal resolution (Cano et al., 1986; Verdebout, 2004) but cover the high northern and southern latitudes, where the ozone depletion is most prominent, at challengingly large viewing angles (Meerkötter et al., 2003).
Europe's first dedicated operational polar orbiting weather satellite program is the EUMETSAT Polar System (EPS), operated by the European Organisation for the Exploitation of Meteorological Satellites (EUMETSAT). The space segment of the EPS consists of a series of three polar orbiting meteorological operational (Metop) satellites. The first two Metop satellites, Metop-A and Metop-B, were launched on 19 October 2006 and 17 September 2012, respectively, with MetopB taking over the prime service on 24 April 2013. The third, Metop-C, is due to be launched in the 2018 time frame. EPS is the European contribution to the Initial Joint Polar System Agreement (IJPS), an agreement between EUMETSAT and National Oceanic and Atmospheric Administration (NOAA). EUMETSAT is responsible for the local morning orbit (daytime descending node around 09:30 LT) while NOAA is responsible for the afternoon orbit (daytime ascending node around 14:30LT), beginning with the NOAA-18, launched on 20 May 2005, and taken over by the current NOAA-19, launched on 6 February 2009, as the prime observer on 23 June 2009.

EUMETSAT ensures maximal benefit from its satellite programs by maintaining a network of Satellite Application Facilities (SAF) within its member states. The SAF on Ozone and Atmospheric Chemistry Monitoring (O3M SAF) focuses on the measurements of the second Global Ozone Monitoring Experiment (GOME-2) aboard the three Metop satellites. The products of the O3M SAF include ozone, trace gas, aerosol and surface UV radiation products. The surface UV radiation products include a near-real-time product based on assimilated total ozone and an offline product utilising level2 total ozone columns. In this paper we describe the version 1.20 of the offline product.

\section{Product description}

\subsection{Overview}

The O3M SAF offline surface UV (OUV) radiation product is a global product containing daily maximum dose rates and daily integrated doses weighted with different biological weighting functions, integrated UVB and UVA radiation, solar noon UV index and daily maximum photolysis frequencies of ozone and nitrogen dioxide at the surface level. The quantities stored in the product are listed in Table 1 and defined in Sect. 2.4. The quantities are computed in a $0.5^{\circ} \times 0.5^{\circ}$ regular latitude-longitude grid and stored as daily files in the hierarchical data format (HDF5) within 2 weeks from sensing. Figure 1 shows an example of the solar noon UV index field. The product is based on radiative transfer modelling using as inputs: GOME-2 total ozone product, cloud optical depth estimated from the channel 1 reflectance of the third Advanced Very High-Resolution Radiometer (AVHRR/3) and climatological aerosol optical depth and surface albedo data (Kujanpää, 2013a). The equa- 
Table 1. Description of the surface UV radiation quantities stored in the OUV product version 1.20. The quantities and the biological weighting functions are defined in Sect. 2.4.

\begin{tabular}{lll}
\hline Quantity name & Unit & Description \\
\hline DailyDoseCie & $\mathrm{kJ} \mathrm{m}^{-2}$ & Daily UV dose, erythemal (CIE) weighting \\
DailyDoseDna & $\mathrm{kJ} \mathrm{m}^{-2}$ & Daily UV dose, DNA damage weighting \\
DailyDosePlant & $\mathrm{kJ} \mathrm{m}^{-2}$ & Daily UV dose, Plant response weighting \\
DailyDoseVitd & $\mathrm{kJ} \mathrm{m}^{-2}$ & Daily UV dose, Vitamin D synthesis weighting \\
DailyDoseUvb & $\mathrm{kJ} \mathrm{m}^{-2}$ & Daily UV dose, integrated UVB radiation \\
DailyDoseUva & $\mathrm{kJ} \mathrm{m}^{-2}$ & Daily UV dose, integrated UVA radiation \\
DailyMaxDoseRateCie & $\mathrm{mW} \mathrm{m}^{-2}$ & Daily maximum dose rate, erythemal (CIE) weighting \\
DailyMaxDoseRateDna & $\mathrm{mW} \mathrm{m}^{-2}$ & Daily maximum dose rate, DNA damage weighting \\
DailyMaxDoseRatePlant & $\mathrm{mW} \mathrm{m}^{-2}$ & Daily maximum dose rate, Plant response weighting \\
DailyMaxDoseRateVitd & $\mathrm{mW} \mathrm{m}^{-2}$ & Daily maximum dose rate, Vitamin D synthesis weighting \\
DailyMaxDoseRateUvb & $\mathrm{mW} \mathrm{m}^{-2}$ & Daily maximum dose rate, integrated UVB radiation \\
DailyMaxDoseRateUva & $\mathrm{mW} \mathrm{m}^{-2}$ & Daily maximum dose rate, integrated UVA radiation \\
DailyMaxJO1D & $\mathrm{s}^{-1}$ & Daily maximum $j_{\mathrm{O}\left({ }^{1} \mathrm{D}\right)}$ at surface level \\
DailyMaxJNO2 & $\mathrm{s}^{2}$ & Daily maximum $j_{\mathrm{NO}}$ at surface level \\
SolarNoonUvIndex & $\mathrm{unitless}^{-1}$ & Solar noon UV index \\
\hline
\end{tabular}

${ }^{1}$ Became available in product version 1.20 on 9 July 2013

2 Was included in version 1.20 on 15 March 2015

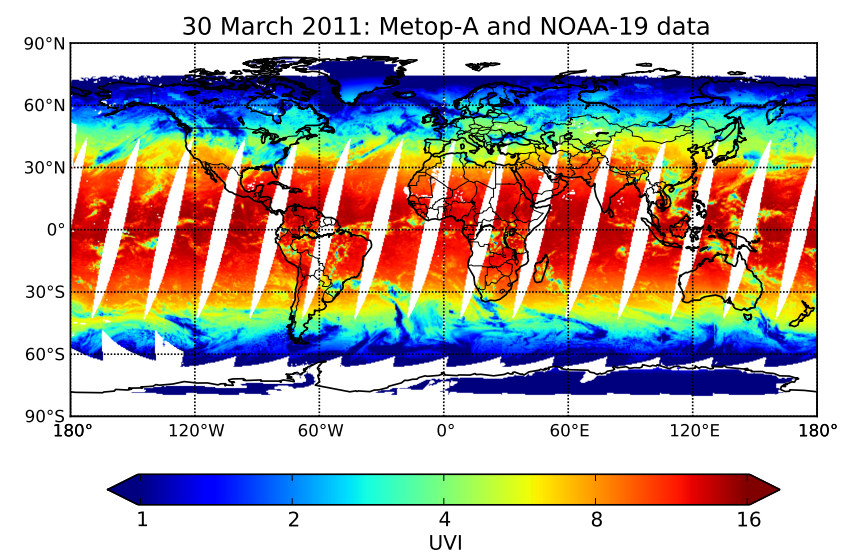

Figure 1. An example product field. Solar noon UV index derived from Metop-A and NOAA-19 data on 30 March 2011 during the Arctic ozone hole episode when exceptionally large values of UV index for the point in time were observed in the Arctic. In Sodankylä, northern Finland, a solar noon UV index of 2.14 was measured at ground level exceeding the climatological value by $100 \%$ (Bernhard et al., 2013). A slightly smaller value of 1.9 is obtained from the OUV product due to averaging of cloud cover over a larger area than is seen by the ground-based instrument. Global coverage of the product is limited by the swath of the GOME-2 instrument leaving stripes at low latitudes. The polar night and the maximum solar zenith angle for cloud processing limit the coverage at high latitudes while cloud-free values are used for the Antarctic and Greenland ice sheets.

torial overpass time of the Metop satellite around 09:30 LT is non-optimal for modelling of surface UV radiation as it fails to capture the maximum UV dose rate region around solar noon. At least two overpasses, one in the morning and another in the afternoon, are therefore needed to satisfactorily approximate the cloud-modulated diurnal cycle (Meerkötter and Bugliaro, 2002). This is achieved by deriving the cloud optical depth from the channel 1 reflectance of the AVHRR/3 instrument aboard both Metop in the morning orbit and the NOAA Polar Orbiting Environmental Satellites (POES) in the afternoon orbit. In addition, more overpasses are used at high latitudes where the swaths of consecutive orbits overlap. Total ozone column is used for two different purposes. It accounts for the reduction of the surface UV irradiance by ozone absorption in the Hartley-Huggins band and for the reduction of the AVHRR/3 channel 1 reflectance by ozone absorption in the Chappuis band (Fig. 2).

\subsection{Input satellite data}

\subsubsection{GOME-2 total ozone product}

GOME-2 is a nadir-viewing scanning UV-VIS (visible) spectrometer measuring back-scattered and reflected radiation from the Earth-atmosphere system in a spectral range between 240 and $790 \mathrm{~nm}$ (Munro et al., 2015). The spectral range is covered by four main optical channels and also by two polarisation measurement devices (PMDs). The polarisation measurements are primarily used to correct for the polarisation sensitivity of the main detectors. The swath width of the GOME-2 scan and the integration time of the channel readouts are programmable. The default $1920 \mathrm{~km}$ swath width and the default integration time of $187.5 \mathrm{~ms}$ result in $80 \mathrm{~km} \times 40 \mathrm{~km}$ (across-track $\times$ along-track) ground pixels in the forward scan giving daily coverage at mid- and high lat- 


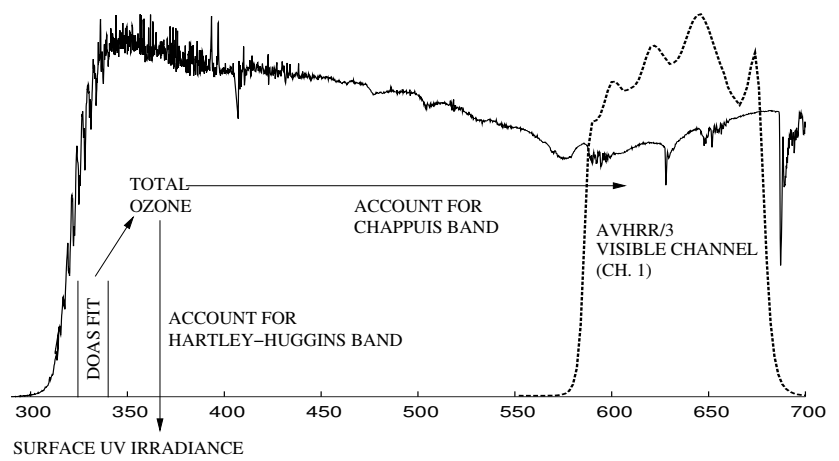

Figure 2. UV-VIS reflectance spectrum (solid line) together with AVHRR/3 channel 1 spectral response function (dotted line) illustrating the use of the total ozone column product derived from 325-335 nm fitting window. The total ozone column accounts both for the Hartley-Huggins band (up to ca. $350 \mathrm{~nm}$ ) absorption in the surface UV irradiance calculation (280-400 nm) and the Chappuis band absorption (wide band covering the whole visible region with two maxima around 575 and $600 \mathrm{~nm}$ ) in retrieving the cloud optical depth from the AVHRR/3 channel 1 reflectance.

itudes but leaving gaps at low latitudes (Fig. 1). To increase the intensity of incoming light, ground pixels with low solar elevation and also the shortest wavelengths subject to strong ozone absorption are measured with a longer integration time. Spectra are also recorded during the backward movement of the scan mirror but the resulting ground pixels are 3 times larger in the across-track direction than the forward scan pixels. A special feature of GOME-2 is that the ground pixel size remains nearly constant over the swath due to a non-linear movement of the scan mirror. In addition to the Earth radiance measurement, a solar irradiance spectrum is measured once a day providing a reference spectrum for atmospheric reflectance.

GOME-2 continues the European contribution to longterm monitoring of atmospheric ozone started by the GOME aboard the second European Remote Sensing satellite (ERS2; launched in 1995) and the Scanning Imaging Absorption spectroMeter for Atmospheric CartograpHY (SCIAMACHY) aboard the Environmental Satellite (Envisat; launched in 2002). Total ozone columns are produced by the German Aerospace Center (DLR) in the framework of the O3M SAF and disseminated to the near-real-time users via EUMETSAT's Multicast Distribution System (EUMETCast). The operational retrieval is based on the GOME data processor (GDP) version 4 family of algorithms using differential optical absorption spectroscopy (DOAS) (Van Roozendael et al., 2006; Loyola et al., 2011). The algorithm consists of a slant column fit of the measured GOME-2 reflectance in a 325-335 nm fitting window covering the Huggins band absorption features of ozone to an equation based on the Lambert-Beer absorption law and including a polynomial closure term to deal with broadband signatures over the fitting window. An iterative air mass factor is used to convert the slant column to vertical column density. The conversion step involves online radiative transfer computations, utilisation of cloud parameters (cloud top height and albedo, effective cloud fraction) obtained in a preprocessing step by an Optical Cloud Recognition Algorithm (OCRA) and Retrieval of Cloud Information using Neural Networks (ROCINN) algorithms (Loyola, 2004; Loyola et al., 2007, 2010; Loyola and Ruppert, 1998), and addition of a climatological ghost column below the cloud level.

Several enhancements to the basic algorithm were introduced in GDP 4.4: improved cloud retrieval algorithms including detection of Sun glint effects, a correction for intracloud ozone, better treatment of snow and ice conditions, accurate radiative transfer modelling for large viewing angles and elimination of scan angle dependencies (Loyola et al., 2011). GDP 4.7 introduced further improvements over the basic algorithm (Hao et al., 2014). Most notably, the ozone absorption cross sections were updated to the BrionDaumont-Malicet (BDM) data set (Daumont et al., 1992; Malicet et al., 1995; Brion et al., 1998).

The UV bands of the GOME-2 instrument suffer from severe throughput degradation (Dikty and Richter, 2011). Although the DOAS approach is relatively insensitive to instrument degradation, the degradation is evident in the increase of the fitting residuals (Hao et al., 2014). A recent validation study, however, indicates that GOME-2 total ozone agrees at the $\pm 1 \%$ level with the standard ground-based Dobson and Brewer measurements and also with corresponding satellite-based data sets from GOME/ERS-2, SCIAMACHY/ENVISAT and OMI/Aura (Koukouli et al., 2012), therefore providing a good quality input data source for radiative transfer modelling of surface UV irradiance.

\subsubsection{AVHRR/3 level 1b product}

The AVHRR/3 aboard the Metop satellites is a heritage instrument provided by NOAA. It is the latest version of the series carried on the POES series of satellites, beginning with a four-channel instrument aboard TIROS-N in 1978 (Robel, 2014). The third version was first carried on NOAA-15 launched in May 1998. The current operational NOAA-19 is the last NOAA satellite carrying AVHRR/3. It has been replaced with the Visible Infrared Imaging Radiometer Suite (VIIRS) in the Suomi-NPP and Joint Polar Satellite System (JPSS) programs. AVHRR/3 is a broad-band six-channel scanner sensing in the visible, near-infrared and thermal infrared spectral regions. The channel 1 is located in the visible at 580-680 nm (Fig. 2) with an effective wavelength of ca. $630 \mathrm{~nm}$ and an equivalent width of ca. $80 \mathrm{~nm}$, the exact values depending on the individual instrument. The swath width is ca. $2900 \mathrm{~km}$, much wider than for GOME-2, providing a daily global coverage also at low latitudes. The onboard processor stores the measurements in two different data formats with different ground pixel sizes. The local area coverage (LAC) data are stored in full resolution of the scanner, 
approximately $1.1 \mathrm{~km}$ at the satellite nadir point. The global area coverage (GAC) format is a thinned and averaged format. First, data are only used from every third scan line. Second, the amount of data are further reduced in the scan line direction by storing only the average value of four adjacent samples and skipping one sample before moving to the next set of four samples. The area covered by a GAC pixel at nadir is therefore formally $3.3 \mathrm{~km} \times 5.5 \mathrm{~km}$ in the along and across track directions, respectively, although only a $1.1 \mathrm{~km} \times 4.4 \mathrm{~km}$ fraction contributes to the signal. Both GAC and LAC pixels increase in size towards the edges of the swath.

Unfortunately, there are no onboard calibration devices for the visible channels. The calibration coefficients determined prior to launch are traceable to the radiance standards maintained at the National Institute of Standards and Technology (NIST) (Robel, 2014). The calibration is known to degrade in orbit and is maintained with vicarious post-launch calibration techniques (Wu et al., 2010). EUMETSAT processes the raw instrument data from Metop AVHRR/3 in LAC format and NOAA AVHRR/3 in GAC format to calibrated and geolocated level $1 \mathrm{~b}$ radiance products, and broadcasts them to the near-real-time users via the EUMETCast system (EUMETSAT, 2011).

\subsection{Auxiliary data grids}

\subsubsection{Surface pressure}

The surface height is obtained from the US Geological Survey's Global 30 Arc-Second (GTOPO30) digital elevation model covering the full extent of latitude from $90^{\circ} \mathrm{S}$ to $90^{\circ} \mathrm{N}$ and the full extent of longitude from $180^{\circ} \mathrm{W}$ to $180^{\circ} \mathrm{E}$ at regularly spaced 30 arcsec (ca. $1 \mathrm{~km}$ ) intervals. The mean surface height together with the minimum and maximum values are computed from the GTOPO30 map for each $0.5^{\circ} \times 0.5^{\circ}$ grid cell. The surface pressure for each grid cell is then obtained from the hydrostatic equation using a scale height of $7.5 \mathrm{~km}$. In this way synoptic variations in surface pressure (high and low pressure systems) are neglected in the processing. The minimum and maximum height grids are used for quality flagging. If the minimum or maximum height differs from the mean value more than a threshold value, currently set to $750 \mathrm{~m}$, the cell is quality flagged as containing an inhomogeneous surface to indicate that the underlying assumption of a homogeneous horizontal surface (Sect. 3.1) is problematic for these grid cells, typically containing mountain slopes or edges of ice sheets.

\subsubsection{Surface albedo and aerosol climatologies}

In order to reduce dependencies on external inputs, the operational algorithm relies on climatologies for the surface albedo and aerosol optical depth. The surface albedo climatology for the $0.5^{\circ} \times 0.5^{\circ}$ latitude-longitude grid was constructed for every day of year based on the presence of snow or ice in each grid cell. Northern hemispheric monthly snow cover extent data (Armstrong and Brodzik, 2010) from the International Satellite Land-Surface Climatology Project, Initiative II (ISLSCP II) (Hall et al., 2006) together with the monthly masks of maximum sea ice extent derived by the National Snow and Ice Data Center (NSIDC) from the sea ice concentrations obtained from passive microwave data (Cavalieri et al., 1996) were used to determine the days of year when snow or ice was present in each grid cell. The monthly Minimum Lambert Equivalent Reflectivity (MLER) climatology (Herman and Celarier, 1997) is then used for regions and time periods with permanent or negligible snow/ice cover while a climatology better capturing the seasonal changes in the surface albedo during the snow/ice melting and formation periods (Tanskanen et al., 2004) is used elsewhere. The surface albedo in the visible wavelength range from ca. 580 to $680 \mathrm{~nm}$ covered by the AVHRR/3 channel 1 deviates from the UV albedo, especially at deserts where the soil minerals absorb the UV more strongly than in the visible wavelengths (Wagner et al., 2012). The difference in UV and visible albedo is accounted for by using the University of Maryland $8 \mathrm{~km}$ land cover data (De Fries et al., 1998) and the dependency of average MLER for different surface types on wavelength, obtained from 5.5 years of GOME observations covering the period June 1995-December 2000 (Koelemeijer et al., 2003). For example, Fig. 3 in Koelemeijer et al. (2003) indicates that over deserts the visible albedo (taken at $610 \mathrm{~nm}$ ) is 3 times larger than the UV albedo (taken at $380 \mathrm{~nm})$.

Partially ice or snow covered grid cells are inhomogeneous with respect to surface albedo, especially near the edges of ice sheets and around small snow or ice covered islands where one part is water with a low UV reflectivity and the other part is ice or snow with a high UV reflectivity. It is assumed that in order for a grid cell to be homogeneous, the area defined by the current cell and its nearest neighbouring cells has to be homogeneous. The minimum and maximum values of surface albedo for this area are determined, and if the difference between the maximum and minimum is larger than a threshold value, currently set to 0.1 , the current grid cell is quality flagged as inhomogeneous to indicate that the surface UV quantities vary significantly within the grid cell due to the surface albedo.

Obtaining reliable aerosol information from satellite measurements is a complicated task (Mishchenko et al., 2007). The wavelength-dependent aerosol signal is often mixed with signals from the surface, trace gas absorption, Rayleigh scattering and scattering from sub-pixel clouds. Combining different satellite-derived aerosol products from different sources is error prone in the operational processor, and therefore the aerosol optical depths, $\tau_{\mathrm{a}}$, at $550 \mathrm{~nm}$ are currently obtained from a monthly climatology (Kinne, 2007) combining aerosol products from various satellite instruments covering the time period from 1979 to 2006, including TOMS, AVHRR, POlarization and Directionality of 

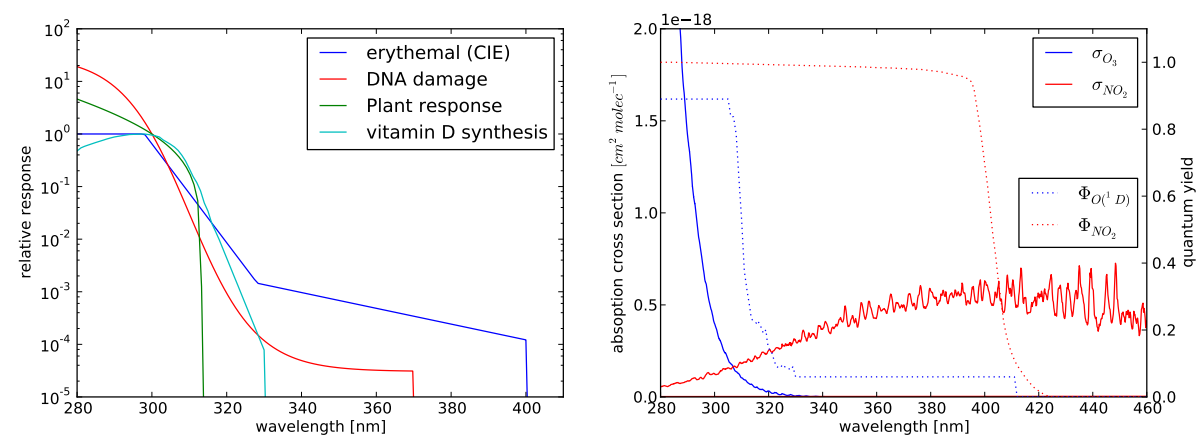

Figure 3. Left: biological weighting functions used in the product. Right: absorption cross sections of ozone and nitrogen dioxide (solid lines, left $y$ axis) together with the quantum yields of their photolysis reactions (dotted lines, right $y$ axis).

the Earth's Reflectances (POLDER), Multi-angle Imaging SpectroRadiometer (MISR) and Moderate-Resolution Imaging Spectroradiometer (MODIS), to a composite that best agrees with the high quality data from the ground-based sunphotometer measurements in the Aerosol Robotic Network (AERONET) (Holben et al., 2001).

\subsection{Product quantities}

\subsubsection{Dose rates and daily integrated doses}

The calculation of dose rates is based on the hemispherical spectral irradiance $E_{\mathrm{h}}\left(\mathrm{W} \mathrm{m}^{-2} \mathrm{~nm}^{-1}\right)$ incident on a horizontal surface at a given time $t$, obtained from

$E_{\mathrm{h}}(\lambda, \tau, t)=\int_{0}^{2 \pi} \mathrm{d} \phi \int_{0}^{\frac{\pi}{2}} L(\lambda, \theta, \phi, \tau, t) \cos \theta \sin \theta \mathrm{d} \theta$,

where $\theta$ and $\phi$ are the zenith and azimuth angles defining the direction of the spectral radiance $L\left(\mathrm{~W} \mathrm{~m}^{-2} \mathrm{sr}^{-1} \mathrm{~nm}^{-1}\right)$ incident on the horizontal surface and $\lambda$ is the wavelength $(\mathrm{nm})$. The atmospheric optical depth $\tau$ is time dependent through variation of the cloud optical depth and total ozone column during the day. For simplicity, parameters assumed to be time independent, such as surface pressure, surface albedo, aerosol optical depth and atmospheric profiles, are not explicitly shown. The incident radiance $L$ includes the direct beam from the Sun and is obtained with radiative transfer modelling (Sect. 3). It depends on time through the variation of the Sun-Earth distance during the year and solar elevation during the day, and also through $\tau$. Time variations in the solar spectrum are neglected. The hemispherical spectral irradiance is multiplied by a given weighting function $w(\lambda)$ and integrated over the wavelength $\lambda$ in a given spectral range $\left[\lambda_{0}, \lambda_{1}\right]$ to give
$E_{\mathrm{w}}^{\prime}(\tau, t)=\int_{\lambda=\lambda_{0}}^{\lambda_{1}} w(\lambda) E_{\mathrm{h}}(\lambda, \tau, t) \mathrm{d} \lambda$.

In this paper, we call the weighted and integrated irradiance $E_{\mathrm{w}}^{\prime}$ the dose rate $\left(\mathrm{W} \mathrm{m}^{-2}\right)$. The dose rate is then integrated over the sunlit part of the day to give the daily dose $H_{\mathrm{W}}\left(\mathrm{J} \mathrm{m}^{-2}\right)$

$H_{\mathrm{w}}=\int_{t=\text { sunrise }}^{\text {sunset }} E_{w}^{\prime}(\tau, t) \mathrm{d} t$

involving interpolation of the optical depth to the integration time steps as described in Sect. 4.2.2. The daily doses obtained for each weighting function described below are stored in the product. Also stored are the daily maximum dose rates $E_{\mathrm{w}, \max }^{\prime}$ for each weighting function, given by

$E_{\mathrm{w}, \max }^{\prime}=\underset{t}{\arg \max } E_{\mathrm{w}}^{\prime}(\tau, t)$,

and the solar noon UV index, obtained by multiplying the erythemal dose rate at solar noon in units $\mathrm{W} \mathrm{m}^{-2}$ by a factor of $40 \mathrm{~m}^{2} \mathrm{~W}^{-1}$ to obtain a unitless number in a convenient scale (WHO, 2002).

The erythemal (CIE) weighting function (McKinlay and Diffey, 1987) describes the response of the human skin to UV radiation causing reddening of the skin (i.e. sunburn). It is defined piecewise as

$w(\lambda)= \begin{cases}1.0 & : 250 \leq \lambda \leq 298 \mathrm{~nm} \\ 10^{0.094(298-\lambda)} & : 298<\lambda \leq 328 \mathrm{~nm} \\ 10^{0.015(139-\lambda)} & : 328<\lambda \leq 400 \mathrm{~nm} .\end{cases}$

The weighting function for DNA damage (Setlow, 1974) describes the ability of UV irradiance to cause damage to unprotected DNA, and is defined by 
$w(\lambda)=\frac{e^{13.82\left(\frac{1.0}{D}-1.0\right)}}{0.0326}, \quad D=1.0+e^{\frac{\lambda-310}{9}}$,

where normalisation to 1.0 at $300 \mathrm{~nm}$ is used (normalisation to $265 \mathrm{~nm}$ is divided by 0.0326 ). The weighting function for generalised plant response (Caldwell, 1971) is defined by

$w(\lambda)=\frac{2.618}{0.2176}\left[1.0-\left(\frac{\lambda}{313.3}\right)^{2}\right] e^{-\frac{\lambda-300}{31.08}}$,

where normalisation to 1.0 at $300 \mathrm{~nm}$ is used (normalisation to $280 \mathrm{~nm}$ is divided by 0.2176 ). Initial versions of the product included the Skin Cancer Utrecht Philadelphia for human beings (SCUP-h) weighting function (De Gruijl and Van der Leun, 1994). In version 1.20, however, it was replaced with the weighting function for the production of previtamin $\mathrm{D}_{3}$ in human skin (in this paper referred to as "vitamin D synthesis" for simplicity), obtained by linear interpolation of the tabulated data published by the CIE (2006). Finally, the weighting function is equal to 1 for integrated UVB and UVA radiation. Figure 3 (left) shows the different weighting functions currently used in the product.

\subsubsection{Photolysis frequencies}

Two important tropospheric photolysis reactions are driven by UV radiation. For the formation of atomic oxygen in its exited ${ }^{1} \mathrm{D}$ state from ozone

$\mathrm{O}_{3}+h v(\lambda<320 \mathrm{~nm}) \rightarrow \mathrm{O}\left({ }^{1} \mathrm{D}\right)+\mathrm{O}_{2}$

the rate constant is $j_{\mathrm{O}\left({ }^{1} \mathrm{D}\right)}$. This is an important photodissociation route of ozone leading to production of hydroxyl radical, a key species in oxidation of hydrocarbons in the troposphere. For the photolysis of nitrogen dioxide

$\mathrm{NO}_{2}+h v(\lambda<420 \mathrm{~nm}) \rightarrow \mathrm{NO}+\mathrm{O}$

the rate constant is $j_{\mathrm{NO}_{2}}$. The atomic oxygen can react with molecular oxygen producing tropospheric ozone.

For the photolysis frequencies, the spherical spectral irradiance (actinic flux) $E_{\mathrm{s}}$, expressed here in photons $\mathrm{s}^{-1} \mathrm{~m}^{-2} \mathrm{~nm}^{-1}$, for a given time is computed from

$E_{\mathrm{S}}(\lambda, \tau, t)=\int_{0}^{2 \pi} \mathrm{d} \phi \int_{0}^{\pi} L(\lambda, \theta, \phi, \tau, t) \sin \theta \mathrm{d} \theta$

and the photolysis frequencies $j_{X}$ in $\mathrm{s}^{-1}$ are obtained by weighting and integrating over wavelength

$j_{X}(\tau, t)=\int_{\lambda} \sigma_{X}(\lambda, T) \Phi_{X}(\lambda, T) E_{\mathrm{s}}(\lambda, \tau, t) \mathrm{d} \lambda$,

where $\sigma_{X}(\lambda, T)$ is the absorption cross section $\left(\mathrm{m}^{2} \mathrm{molec}^{-1}\right)$ and $\Phi_{X}(\lambda, T)$ is the photolysis quantum yield $\left(\right.$ molec photon $\left.^{-1}\right)$ for species $X$. For the $O\left({ }^{1} \mathrm{D}\right)$ reaction, the BDM absorption cross sections are used while the quantum yields are from Talukdar et al. (1998). For the $\mathrm{NO}_{2}$ reaction, absorption cross sections by Schneider et al. (1987) and quantum yields from DeMore et al. (1997) are used. The absorption cross sections and quantum yields are plotted in Fig. 3 (right). The daily maximum $j_{\mathrm{O}\left({ }^{1} \mathrm{D}\right)}$ at the surface level was introduced in product version 1.20 on 9 July 2013, and the daily maximum $j_{\mathrm{NO}_{2}}$ was included on 15 March 2015.

\section{Radiative transfer modelling}

The radiative transfer (RT) modelling involves building of model atmospheres characterised by surface pressure, surface albedo, cloud optical depth, aerosol optical depth and vertical profiles of temperature and ozone number density (Sect. 3.1). To ensure that the cloud optical depth retrieved from the AVHRR/3 channel 1 reflectance is consistent with the computation of the surface UV quantities, the same model atmospheres are used in computing the look-up tables for the cloud optical depth (Sect. 3.2) and for the dose rates and photolysis frequencies (Sect. 3.3).

\subsection{Atmospheric input}

The model atmosphere contains 30 homogeneous layers above a horizontally homogeneous Lambertian surface. The layer thickness is 1 up to $15 \mathrm{~km}$ in height and then gradually increases to $8 \mathrm{~km}$ in the topmost layer between 62 and $70 \mathrm{~km}$, taken as the top-of-the-atmosphere (TOA). All layers contain air $\left(\mathrm{N}_{2}, \mathrm{O}_{2}\right)$ and ozone (absorption by other minor trace gases such as $\mathrm{SO}_{2}$ is neglected). The temperature and ozone number density of each layer are based on the TOMS V7 climatology (Wellemeyer et al., 1997). Rayleigh scattering coefficient and the depolarisation factor of air are obtained from the equations (Chance and Spurr, 1997) fitted to the data of Bates (1984) while the ozone absorption coefficient is from the BDM data set. In addition, the first $1 \mathrm{~km}$ layer above the surface may contain aerosols while the second $1 \mathrm{~km}$ layer may contain a cloud. The cloud and aerosol layers are assumed to be homogeneous. Cloud droplets and aerosol particles are modelled as spherical Mie scatterers. Cloud droplet distribution is the Deirmendjian C1 model (Deirmendjian, 1969). Ice clouds and high altitude cirrus clouds are not treated separately in the current algorithm. The water-soluble aerosol model at $0 \%$ humidity (waso00) of the GADS database (Koepke et al., 1997) is used to model the aerosol optical properties. Expansion coefficients of the scattering matrix for clouds and aerosols are computed with a Mie program (De Rooij and Van der Stap, 1984). The extraterrestrial solar spectrum is a composite used in the LibRadtran model (available at http://www.libradtran.org). It is the ATLAS-3 solar spectrum up to $407.8 \mathrm{~nm}$, then the ATLAS- 2 up to $419.9 \mathrm{~nm}$, and from 
Table 2. Node points of the cloud optical depth look-up table. A subset of the TOMS V7 ozone profile climatology is used together with the associated temperature profiles. M125, M325 and M575 refer to the middle latitude profiles for total ozone columns of 125, 325 and 575 DU, respectively.

\begin{tabular}{llll}
\hline Parameter & Symbol & Unit & Node values \\
\hline Solar zenith angle & $\theta_{0}$ & degree & $0,5,10, \ldots, 80$ \\
Viewing zenith angle & $\theta$ & degree & $0,5,10, \ldots, 70$ \\
Relative azimuth angle & $\Delta \phi$ & degree & $0,20,40, \ldots, 180$ \\
Surface pressure & $p_{\mathrm{S}}$ & atm & $0.7,1.0$ \\
Surface albedo & $A_{\mathrm{S}}$ & - & $0,0.3,0.6,1.0$ \\
Aerosol optical depth $(550 \mathrm{~nm})$ & $\tau_{\mathrm{a}}$ & - & $0,0.2,0.4,0.6,0.8,1.0$ \\
Cloud optical depth & $\tau_{\mathrm{c}}$ & - & $0,0.5,1.0,2.0,4.0,8.0,16.0,32.0,64.0,128.0$, \\
& & & $256.0,500.0$ \\
TOMS V7 profiles & - & - & M125, M325, M575 \\
\hline
\end{tabular}

then on the re-calibrated Kurucz et al. (1984) solar spectrum (Fontenla et al., 1999), known as the MODerate resolution atmospheric TRANsmission (MODTRAN) 3.5 spectrum. The vector linearised discrete ordinate radiative transfer (VLIDORT) model (Spurr, 2006) is used to compute both the surface irradiance and the AVHRR/3 channel 1 reflectance at the node points of the look-up tables described in the following sections.

\subsection{Cloud optical depth look-up table}

The attenuation of radiation through the homogeneous cloud layer in our model is described by cloud optical depth $\tau_{\mathrm{c}}$, following the Lambert-Beer law. Cloud optical depth retrieval is based on the AVHRR/3 channel 1 (centred at ca. $630 \mathrm{~nm}$, Fig. 2) reflectance $R_{1}$

$R_{1}=\frac{\pi L_{1} d^{2}}{\mu_{0} E_{0,1}}$,

where $d$ is the Sun-Earth distance in astronomical units (au), $L_{1}$ is the upwelling in-band radiance, $E_{0,1}$ is the in-band solar irradiance at 1 au on a plane perpendicular to the rays and $\mu_{0}$ is the cosine of the solar zenith angle. To model the reflectance, the upwelling spectral radiance $L^{\prime}(\lambda)$ at TOA for unit solar irradiance is computed with the radiative transfer model for the node points listed in Table 2 in a coarseresolution wavelength grid covering the wavelength region from 550 to $750 \mathrm{~nm}$. The in-band radiance $L_{1}$ for channel 1 is then obtained using the normalised channel 1 response function $g_{1}$ from

$L_{1}=\int_{\lambda_{1}}^{\lambda_{2}} L^{\prime}(\lambda) E_{0}(\lambda) g_{1}(\lambda) \mathrm{d} \lambda$,

where $E_{0}$ is the extraterrestrial solar spectrum defined in Sect. 3.1. The spectral radiance and the response function are linearly interpolated to the high-resolution wavelength grid of the extraterrestrial solar irradiance spectrum before trapezoidal integration of Eq. (11). The in-band extraterrestrial solar irradiance is obtained from

$E_{0,1}=\int_{\lambda_{1}}^{\lambda_{2}} E_{0}(\lambda) g_{1}(\lambda) \mathrm{d} \lambda$,

and the ratio $L_{1} / E_{0,1}$ is stored in the look-up table. Figure 4 shows a typical dependence of the channel 1 reflectance on the cloud optical depth together with the derivative indicating the change in the reflectance for a unit change in the cloud optical depth. As expected, the reflectance saturates at large cloud optical depths for low surface albedo. On the other hand, the reflectance becomes independent of cloud optical depth as the surface albedo approaches unity. These two effects are consistent with the results of Xiong et al. (2002) and are reflected in the product quality flags (Sect. 4.2.3). The dependence of the reflectance on the cloud optical depth also decreases with increasing solar zenith and viewing angles (not shown), and therefore the cloud optical depth is retrieved only when the solar zenith angle is smaller than a limiting value, currently set to $70^{\circ}$. Surface albedo node $A_{\mathrm{s}}=1$ is an extreme case and does not occur in nature. However, it is a convenient upper limit for the look-up tables.

\subsection{Dose rate and photolysis frequency look-up table}

The dose rates (Eq. 2) and photolysis frequencies (Eq. 9) are computed at the node points listed in Table 3 and stored in a look-up table to speed up the processing. The hemispherical irradiance at surface level for unit solar irradiance, i.e. hemispherical transmittance, is obtained from the output of the radiative transfer model in a coarse-resolution wavelength grid with $1 \mathrm{~nm}$ separation from 290 to $341 \mathrm{~nm}$ and then $5 \mathrm{~nm}$ separation from 345 to $400 \mathrm{~nm}$. The hemispherical transmittance is linearly interpolated to the wavelengths (in air) of the high-resolution extraterrestrial solar spectrum $E_{0}$, and the two are multiplied. The dose rates for each weighting function are then calculated from Eq. (2) by trapezoidal integration and stored in the look-up table. Figure 5 shows a typi- 
Table 3. Node points of the look-up table for the dose rates and photolysis frequencies. The full 26 profile set of the TOMS V7 climatology is used. L, M and H refer to the low, middle and high latitude profiles, respectively, while the numbers refer to total ozone columns in DU.

\begin{tabular}{llll}
\hline Parameter & Symbol & Unit & Node values \\
\hline Solar zenith angle & $\theta_{0}$ & degree & $0,5,10, \ldots, 85,88$ \\
Surface pressure & $p_{\mathrm{S}}$ & atm & $0.7,1.0$ \\
Surface albedo & $A_{\mathrm{s}}$ & - & $0,0.1,0.2, \ldots, 1.0$ \\
Aerosol optical depth $(550 \mathrm{~nm})$ & $\tau_{a}$ & - & $0,0.1,0.2, \ldots, 1.0$ \\
Cloud optical depth & $\tau_{\mathrm{c}}$ & - & $0,0.39,0.92,1.7,2.7,4.1,6.1,8.9,13,18$, \\
& & & $25,36,50,70,96,130,190,260,360,500$ \\
TOMS V7 profiles & - & - & L225, L275, ., L475 \\
& & & M125, M175,... M575 \\
& & & H125, H175,..H575 \\
\hline
\end{tabular}

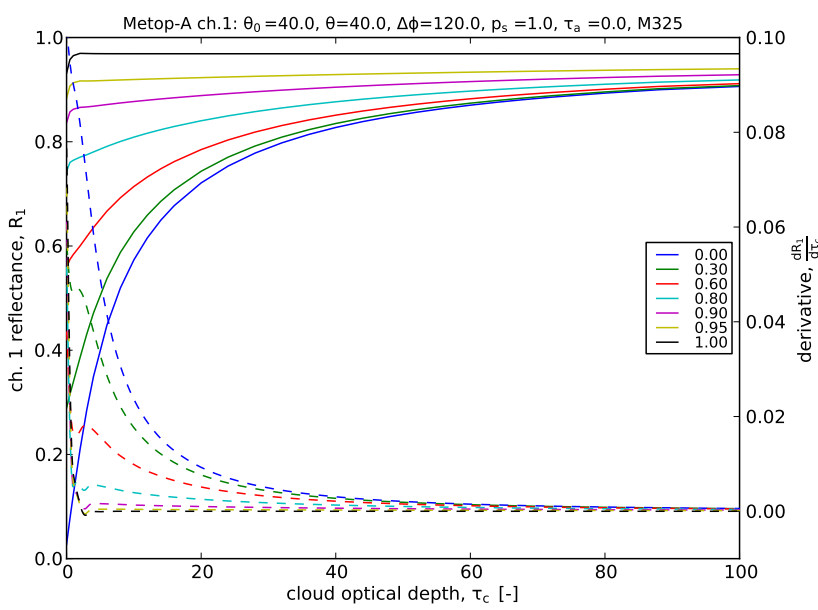

Figure 4. Typical dependence of the AVHRR/3 channel 1 reflectance on cloud optical depth for different surface albedos (solid lines, left $y$ axis) together with the derivative (dashed lines, right $y$ axis) indicating the change in the reflectance for a unit change in the cloud optical depth. Symbols are defined in Table 2.

cal dependence of the erythemal dose rate on cloud optical depth for different surface albedos together with the relative derivative indicating the percent change in the dose rate for a unit change in the cloud optical depth. The percent change decreases with increasing cloud optical depth for the three smallest surface albedos. When the surface albedo is equal to unity, the percent change is small and almost constant. The impact of these dependencies on the product quality flags is discussed in Sect. 4.2.3.

Similarly, the spherical irradiance (actinic flux) at the surface level for unit solar irradiance, i.e. spherical transmittance, is obtained from the output of the radiative transfer model in the same wavelength grid but extended from 400 to $430 \mathrm{~nm}$ with $5 \mathrm{~nm}$ separation. The photolysis frequencies are then calculated from Eq. (9) by trapezoidal integration and stored in the look-up table.

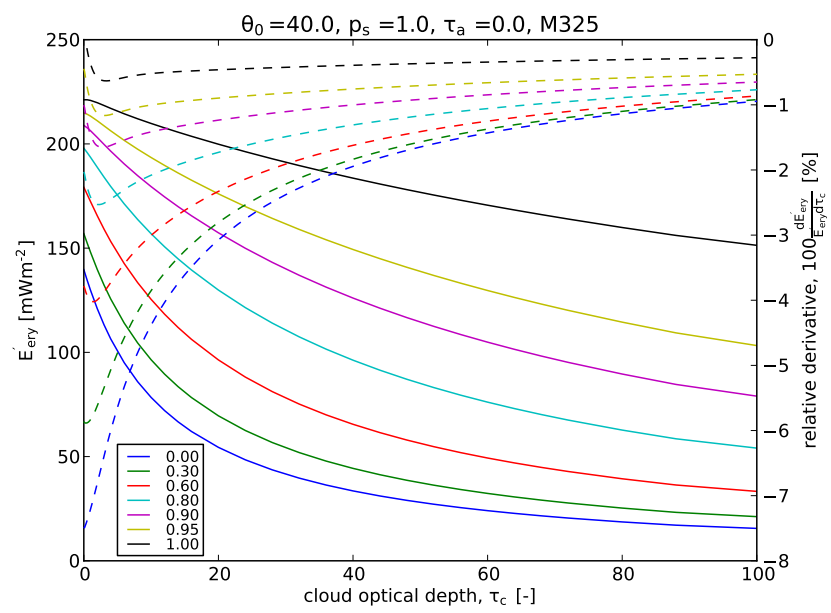

Figure 5. Typical dependence of the erythemal dose rate on cloud optical depth for different surface albedos (solid lines, left $y$ axis) together with the relative derivative (dashed lines, right $y$ axis) indicating the percent change in the dose rate for a unit change in the cloud optical depth. Symbols are defined in Table 3.

\section{Data processing}

\subsection{Processing sites and dataflow}

The product is processed at the Finnish Meteorological Institute (FMI) in Helsinki, Finland, as part of the distributed O3M SAF data processing network. The near-real-time total ozone column product is produced by the DLR in Oberpfaffenhofen, Germany. The AVHRR/3 level $1 \mathrm{~b}$ data both from Metop and NOAA satellites are processed at the EUMETSAT headquarters in Darmstadt, Germany. The satellite data are transmitted between the processing sites with the EUMETCast: a multi-service dissemination system based on standard Digital Video Broadcast technology utilising commercial telecommunication geostationary satellites. The product is archived in the O3M SAF distributed archive at the Sodankylä Satellite Data Centre, Finland. An online catalogue of the products is maintained at the EUMETSAT Data 
Centre, and the products can be ordered from there. The version 1.20 is available from 9 July 2013. The latest information is given at the website http://o3msaf.fmi.fi/products/ouv. html.

\subsection{Processing algorithm}

Figure 6 shows a flowchart of the overall processing steps together with the data and look-up tables involved. The product quantities are computed in a $0.5^{\circ} \times 0.5^{\circ}$ regular latitudelongitude grid, and therefore two preprocessing steps are performed to collect the daily input data to the processing grid. In the first step, the GOME-2 total ozone data from each overpass available for the current day are mapped to the grid by sampling the pixel area and computing the average of the samples hitting a given grid cell during a given overpass. The grid cell is flagged as missing data if no ozone data are available. The resulting daily ozone grid is stored in an intermediate file. In the second step, the cloud optical depth for each available overpass is retrieved from the AVHRR/3 level $1 \mathrm{~b}$ data using the intermediate ozone grid together with climatological data (Sect. 4.2.1). The resulting cloud optical depths are stored in another intermediate file. Finally, the output quantities are interpolated from the look-up table in the main processing step (Sect. 4.2.2).

\subsubsection{Preprocessing of AVHRR/3 data}

Cloud optical depth is retrieved from the channel 1 reflectance of AVHRR/3 aboard Metop and NOAA satellites. One satellite, nominally the prime, from both programmes is used at any given time. Figure 7 shows the average number of cloud observations obtained from AVHRR/3 using the operational combination of Metop-A with either NOAA-18 or NOAA-19 during the period from 1 June 2007 to 31 December 2012. As expected, one cloud observation from each satellite is obtained at low latitudes while more than five are obtained at high latitudes in the summer.

The cloud optical depth is retrieved in the lowest common spatial resolution, i.e. the GAC resolution of the NOAA data, and therefore the Metop LAC-resolution data are thinned and averaged to the GAC resolution prior to processing. The $L_{1} / E_{0,1}$ ratios are computed from the radiance and solar irradiance given in the level $1 \mathrm{~b}$ data file, and the cloud optical depth is interpolated from the look-up table for each GAC pixel. The measurement is discarded if its value is out of the range of the look-up table. For each overpass of a given grid cell, the cloud optical depths of GAC pixels hitting the cell are averaged to form a grid cell average observation at an average overpass time. Taking the average is consistent with the assumption of a homogeneous cloud layer (Sect. 3.1), but due to the non-linear dependence of the reflectance on cloud optical depth (Fig. 4) leads to an error in cloudiness situations involving averaging over very large cloud optical depth differences, such as partial cloudiness. In future versions of the algorithm, the high spatial resolution of the Metop LAC data can be exploited to improve the modelling of partial cloudiness.

The AVHRR/3 ground pixels at the GAC resolution are smaller than the $0.5^{\circ} \times 0.5^{\circ}$ grid cell used for the surface height and albedo grids. In the cloud optical depth retrieval it is assumed that the grid cell is sufficiently homogeneous with respect to the surface properties to allow for using the $0.5^{\circ} \times 0.5^{\circ}$ surface property grids for the GAC pixels. As discussed in Sect. 2.3, a quality flag is set if the surface properties are too inhomogeneous according to the predefined criteria.

\subsubsection{Main processing step}

The sunlit part of the diurnal cycle is discretised with a halfhour time steps from sunrise to sunset taken as the times when the solar zenith angle is $88^{\circ}$, the largest value in the dose rate and photolysis frequency look-up table. The grid average total ozone and cloud optical depth observations $O_{\text {ovp }}$ for each overpass time are interpolated to the times of the diurnal cycle using the nearest neighbour interpolation, represented by

$O\left(t_{\mathrm{d}}\right)=O_{\mathrm{ovp}}\left(i_{\mathrm{ovp}}\right)$

where $i_{\text {ovp }}$ is the index of the overpass closest in time to the diurnal time $t_{\mathrm{d}}$. This approach avoids the possibly large errors in the observations measured with large solar zenith angles early in the morning or late in the evening affecting the important high dose rate region near noon. For cloud optical depth observations retrieved only for $\theta_{0}<70^{\circ}$ (Sect. 3.2), this means that a constant value for $\tau_{\mathrm{c}}$ is assumed between $70^{\circ}<\theta_{0}<88^{\circ}$, although the value can be different in the morning and evening. If no cloud observations are available, the grid cell is flagged as missing data, except on the Greenland and Antarctica ice sheets where cloud-free conditions are always assumed (Sect. 4.2.3). The dose rates and photolysis frequencies are then interpolated from the look-up table using the interpolated ozone and cloud optical depth values. The aerosol optical depth and surface albedo are constant for a given day and taken from climatologies as described in Sect. 2.3. The diurnal integral given by Eq. (3) is evaluated using trapezoidal integration over the half-hourly values. The daily maximum values are computed from Eq. (4) and the solar noon UV index is obtained from the diurnal data point referring to the solar noon. The values are stored in a HDF5 file as described in the product user manual (Kujanpää, 2013b).

Figure 8 compares the diurnal erythemal dose rates extracted from the product processing with ground-based measurements using a UVB Biometer model 501 radiometer from Solar Light Co. (SL-501) in Sodankylä $\left(67.37^{\circ} \mathrm{N}\right.$, $26.63^{\circ} \mathrm{E}$ ) on selected days in June 2007 with different cloud cover. On the fairly clear day of 2 June, the modelled and the measured dose rates matched well. As expected, more deviations are seen on the cloudy days of 3, 6 and 20 June be- 


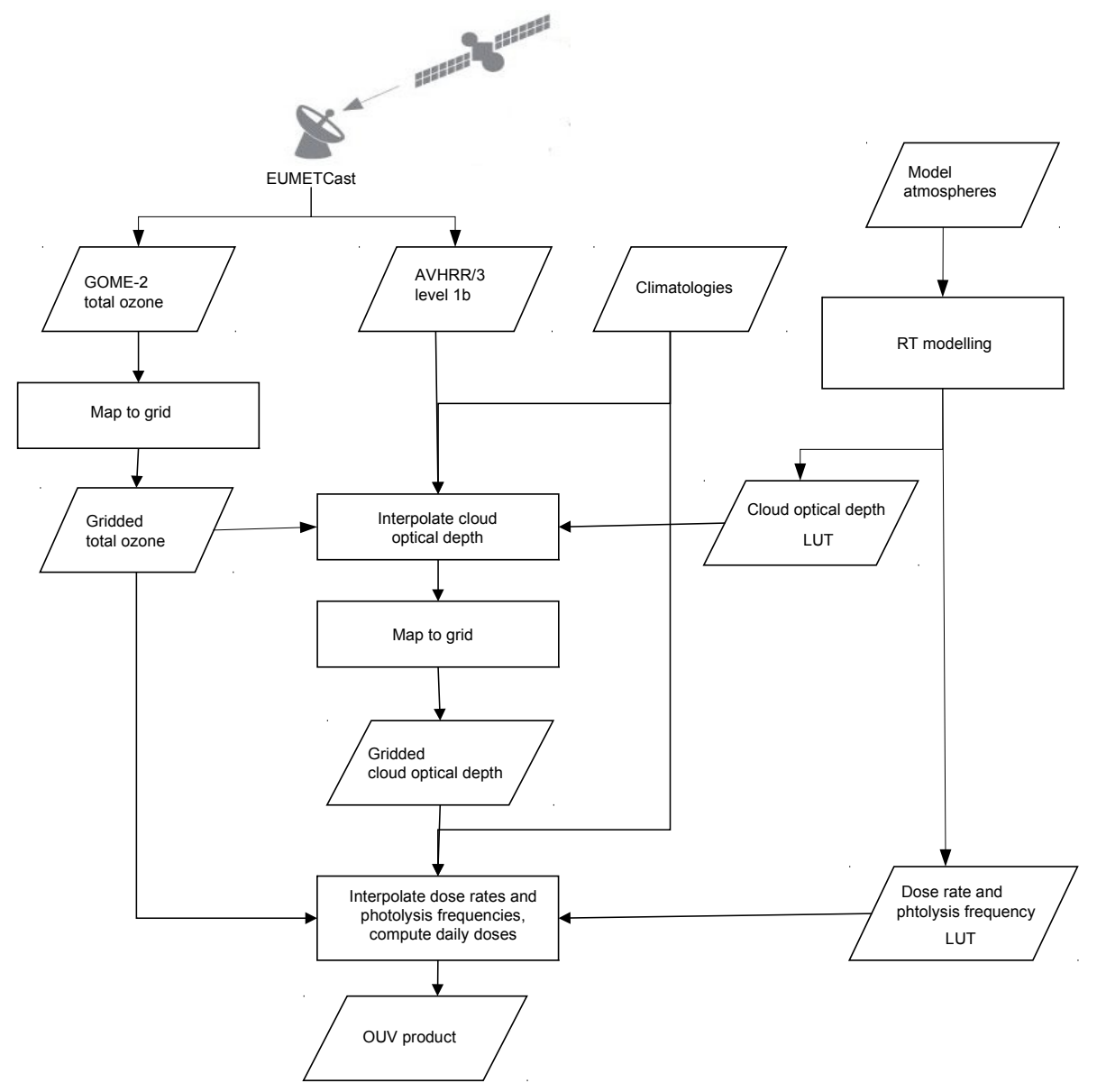

Figure 6. Overall processing algorithm. The radiative transfer modelling illustrated on the right side is performed offline and the results are stored in look-up tables (LUT). The input satellite data are received from the EUMETCast system. The GOME-2 total column ozone product is mapped to the processing grid and then used together with the climatologies in both deriving the intermediate cloud optical depths from the AVHRR/3 level $1 \mathrm{~b}$ data and interpolating the output products from the look-up table.

cause the spatial and temporal sensitivity of the two methods are different. The ground-based values are measured every $10 \mathrm{~min}$ on a very confined area, therefore reacting to every single piece of cloud passing over the measurement site. The satellite data, on the other hand, represent half-hourly averages in the $0.5^{\circ} \times 0.5^{\circ}$ grid cell (ca. $55 \mathrm{~km} \times 21 \mathrm{~km}$ at this latitude). Despite these differences in the two data sets, the overall shape of the diurnal cycle is captured demonstrating the usefulness of multiple overpasses during the day.

\subsubsection{Quality control}

A number of quality flags are set during the product processing to indicate the expected quality for each grid cell. The flags related to surface homogeneity were already discussed in Sect. 2.3. Clouds are a major source of error, and therefore several flags related to clouds are shortly discussed here. Figure 9 shows the dependence of the erythemal dose rate on the channel 1 reflectance for different surface albedos derived from data shown in Figs. 4 and 5. Also shown is the absolute value of the elasticity $\epsilon$ of the dependence

$\epsilon=\frac{R_{1} \mathrm{~d} E_{\text {ery }}^{\prime}}{E_{\text {ery }}^{\prime} \mathrm{d} R_{1}}$,

giving the percent change in the erythemal dose rate with respect to a percent change in the channel 1 reflectance. At large reflectances the elasticity increases rapidly with reflectance and is ca. $15 \%$ at a reflectance of 0.9 . Even after the vicarious in-orbit calibration procedures, the error in the AVHRR/3 channel 1 reflectance tends to exceed the $1 \%$ level (Wu et al., 2010; Xiong et al., 2002) and the error in the erythemal dose rate becomes too large at this limiting reflectance. The exact reflectance limit depends on measurement geometry and atmospheric assumptions (not shown). Currently a limiting cloud optical depth of 80 is used to set a quality flag warning for thick clouds (Fig. 4). On the other hand, at a very high surface albedo close to unity no cloud optical depth can be retrieved from the channel 1 reflectance as indicated by the close-to-zero derivative in Fig. 4 and the 


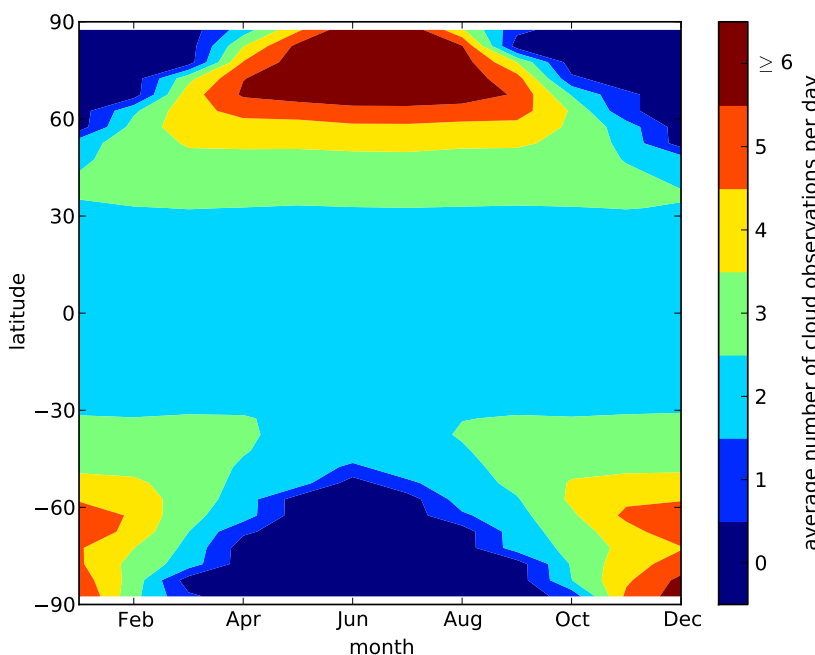

Figure 7. Average number of cloud observations per day obtained from AVHRR/3 using the operational combination of Metop-A with either NOAA-18 or NOAA-19 during the period from 1 June 2007 to 31 December 2012. The average is calculated from the intermediate gridded cloud optical depth file (Fig. 6) for each month in $5^{\circ}$ zonal bands. In the Antarctic region, the number of successful cloud observations is reduced due to high surface albedo. During the quality control, the cloud observations over highly reflecting surfaces are ignored and clear-sky conditions are assumed (see Sect. 4.2.3).

abrupt behaviour of the elasticity in Fig. 9. In the interior parts of the Greenland and Antarctica ice sheets; however, typical clouds are optically thin $\left(\tau_{\mathrm{c}}<1\right)$ (Konzelmann et al., 1994; Mahesh et al., 2001), and therefore cloud-free conditions are assumed for these regions. This is seen in Fig. 1 where the ice sheets have valid values beyond the limiting solar zenith angle of $70^{\circ}$ set by the cloud optical depth retrieval. The limiting values of the quality flag settings are subject to change during the evolution of the processor and up-todate values can be found in the product user manual (Kujanpää, 2013b) and the product specific metadata section of the HDF5 file.

Overall consistency of the latest processed product with the existing data record is verified by monitoring the global average value of the erythemal daily dose. The monitoring results are shown on an online quality monitoring page at the O3M SAF web site. An intercomparison of the product with traditional ground-based surface UV measurements will be presented in a separate paper.

\section{Summary and outlook}

The operational surface UV product of the O3M SAF was described. The product requires information on clouds, ozone, aerosols and surface albedo. In the operational version the cloud optical depth and total column ozone are derived from measurements while the aerosol and surface albedo infor-
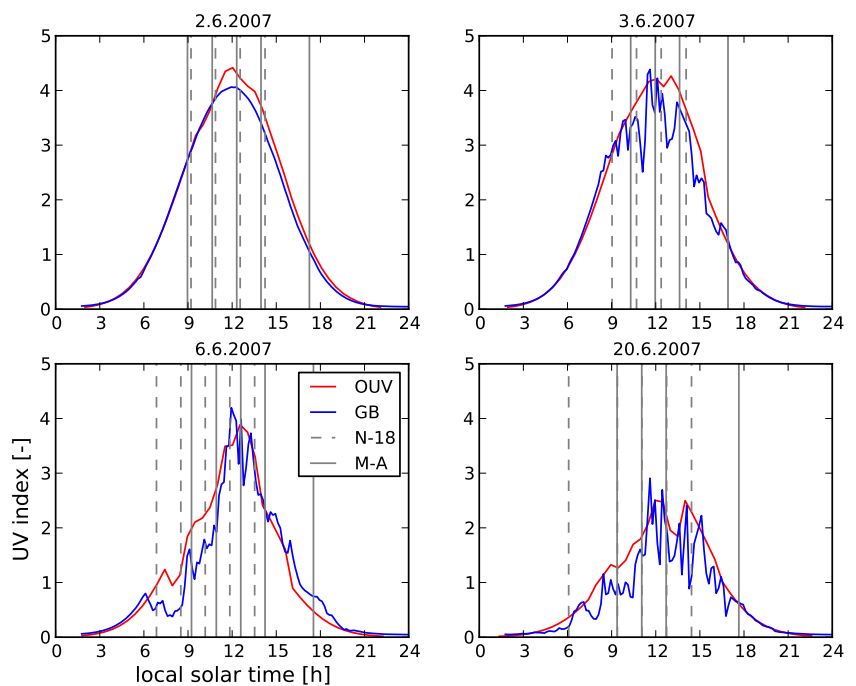

Figure 8. Intercomparison of the diurnal UV index extracted from the products (reprocessed with the algorithm version 1.20) and the corresponding ground-based SL-501 measurements (GB) in Sodankylä $\left(67.37^{\circ} \mathrm{N}, 26.63^{\circ} \mathrm{E}\right)$, Finland, on selected days in June 2007 when Metop-A (M-A) and NOAA-18 (N-18) were used for sampling of the cloud optical depth. Vertical lines mark the times of the satellite overpasses used. The consecutive overpasses are roughly $100 \mathrm{~min}$ apart and vary slightly during the orbit repeat cycle for both satellites. As a result, the overpasses from the two satellites can be very close to each other in time. The apparent missing overpasses are due to the quality control of the cloud optical depth observations (Sects. 4.2.1 and 4.2.3).

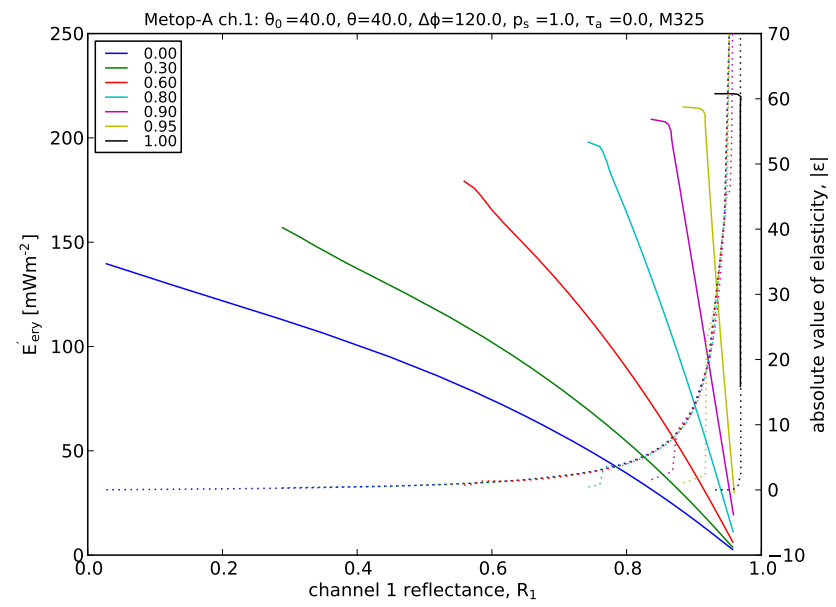

Figure 9. The dependence of the erythemal dose rate on the channel 1 reflectance for different surface albedos derived from data shown in Figs. 4 and 5 (solid lines, left $y$ axis) together with the elasticity (dashed lines, right $y$ axis) indicating the percent change in the dose rate with respect to a percent change in channel 1 reflectance. Symbols are defined in Table 2.

mation come from climatologies. Future product developments aim at replacing these climatologies with measured 
data. A number of suitable products derived from GOME-2 measurements are evolving and new data sets have recently become available. The O3M SAF Lambertian Equivalent Reflectivity (LER) data records derived either from the GOME2 main channels or from the PMD measurements (Tilstra et al., 2014) are promising candidates for a source of surface albedo data both in the UV and visible wavelengths. Also several aerosol products are being derived from Metop data. The operational absorbing aerosol index (De Graaf et al., 2014) and the evolving Polar Multi Sensor Aerosol (Grzegorski, 2014) products are good candidates for replacing the aerosol climatologies. The high spatial resolution of the Metop AVHRR/3 LAC data and other AVHRR/3 channels currently unexploited provide possibilities for improving the modelling of the cloud cover (Han et al., 1999; Xiong et al., 2002). In the operational processing chain, the processor versions of the product and its inputs change with time together with the calibration of the GOME-2 and AVHRR/3 level $1 \mathrm{~b}$ radiance data. Therefore, reprocessing activities are foreseen to provide data records with homogeneous algorithm versions for trend studies. As mentioned in Sect. 2.2.2, AVHRR/3 has been replaced by VIIRS in the NOAA side, and therefore, OUV processing is being adapted to use VIIRS measurements. Finally, possibilities to improve the sampling of the diurnal cloud cover over Europe with measurements of geostationary satellites are being studied.

Acknowledgements. Development of the O3M SAF surface UV product has been funded by EUMETSAT. The operational NOAA AVHRR/3 data were obtained via EUMETSAT within the IJPS programme and for offline use from the NOAA Comprehensive Large Array-data Stewardship System (CLASS). The GTOPO30 data were available from the US Geological Survey and the snow and ice data from the National Snow and Ice Data Center (NSIDC), University of Colorado, Boulder. The GADS aerosol data were obtained from the Meteorological Institute of the University of Munich, Germany, and the MLER data were obtained from the NASA TOMS team. We also wish to thank Robert Spurr from the RT Solutions Inc. for providing the VLIDORT radiative transfer model and Stephan Kinne at MPI Hamburg for providing the aerosol climatology.

Edited by: P. Stammes

\section{References}

Andrady, A., Hamid, S., Hu, X., and Torikai, A.: Effects of increased solar ultraviolet radiation on materials, J. Photoch. Photobio. B, 46, 96-103, doi:10.1016/S1011-1344(98)00188-2, 1998.

Armstrong, R. and Brodzik, M. J.: ISLSCP II Northern Hemisphere monthly snow cover extent, ISLSCP Initiative II Collection, in: ISLSCP Initiative II Collection. Data set, edited by: Hall, R. G., Collatz, G., Meeson, B., Los, S., Brown de Colstoun, E., and Landis, D., available at: http://daac.ornl.gov/ from
Oak Ridge National Laboratory Distributed Active Archive Center, Oak Ridge, Tennessee, USA, doi:10.3334/ORNLDAAC/982, 2010.

Bates, D.: Rayleigh scattering by air, Planet. Space Sci., 32, 785790, doi:10.1016/0032-0633(84)90102-8, 1984.

Bernhard, G., Dahlback, A., Fioletov, V., Heikkilä, A., Johnsen, B., Koskela, T., Lakkala, K., and Svendby, T.: High levels of ultraviolet radiation observed by ground-based instruments below the 2011 Arctic ozone hole, Atmos. Chem. Phys., 13, 10573-10590, doi:10.5194/acp-13-10573-2013, 2013.

Brion, J., Chakir, A., Charbonnier, J., Daumont, D., Parisse, C., and Malicet, J.: Absorption spectra measurements for the ozone molecule in the 350-830 nm region, J. Atmos. Chem., 30, 291299, doi:10.1023/A:1006036924364, 1998.

Bugliaro, L., Mayer, B., Meerkötter, R., and Verdebout, J.: Potential and limitations of space-based methods for the retrieval of surface UV-B daily doses: a numerical study, J. Geophys. Res.Atmos., 111, D23207, doi:10.1029/2005JD006534, 2006.

Caldwell, M. M.: Solar UV irradiation and the growth and development of higher plants, in: Photophysiology, edited by: Giese, A. G., vol. 6, Academic Press, New York, 131-177, 1971.

Cano, D., Monget, J., Albuisson, M., Guillard, H., Regas, N., and Wald, L.: A method for the determination of the global solar radiation from meteorological satellite data, Sol. Energy, 37, 31-39, doi:10.1016/0038-092X(86)90104-0, 1986.

Cavalieri, D. J., Parkinson, C. L., Gloersen, P., and Zwally, H.: Sea Ice Concentrations from Nimbus-7 SMMR and DMSP SSM/I-SSMIS Passive Microwave Data, NASA DAAC at the National Snow and Ice Data Center, Boulder, Colorado, USA, doi:10.5067/8GQ8LZQVL0VL, 1996.

Chance, K. V. and Spurr, R. J. D.: Ring effect studies: Rayleigh scattering, including molecular parameters for rotational Raman scattering, and the Fraunhofer spectrum, Appl. Optics, 36, 52245230, doi:10.1364/AO.36.005224, 1997.

CIE: Action spectrum for the production of previtamin D3 in human skin, Tech. Rep. 174, Commission Internationale de l'Eclairage (International Commission on Illumination), Vienna, Austria, 2006.

Cory, R. M., Ward, C. P., Crump, B. C., and Kling, G. W.: Sunlight controls water column processing of carbon in arctic fresh waters, Science, 345, 925-928, doi:10.1126/science.1253119, 2014.

Daumont, D., Brion, J., Charbonnier, J., and Malicet, J.: Ozone UV spectroscopy I: Absorption cross-sections at room temperature, J. Atmos. Chem., 15, 145-155, 1992.

De Fries, R. S., Hansen, M., Townshend, J. R. G., and Sohlberg, R.: Global land cover classifications at $8 \mathrm{~km}$ spatial resolution: the use of training data derived from Landsat imagery in decision tree classifiers, Int. J. Remote Sens., 19, 3141-3168, doi:10.1080/014311698214235, 1998.

De Graaf, M., Tuinder, O., Tilstra, G., and Penning de Vries, M.: ATBD for the GOME-2 Aerosol products, O3MSAF/KNMI/ATBD/002, Issue 2.33, November 2014, available at: http://o3msaf.fmi.fi/docs/atbd/Algorithm_Theoretical_ Basis_Document_ARS_Nov_2014.pdf, 2014.

De Gruijl, F. and Van der Leun, J.: Estimate of the wavelength dependency of ultraviolet carcinogenesis in humans and its relevance to the risk assessment of a stratospheric ozone depletion, Health Phys., 67, 319-325, 1994. 
Deirmendjian, D.: Electromagnetic Scattering on Spherical Polydispersions, American Elsevier Publishing Company Inc., New York, 1969.

DeMore, W. B., Sander, S. P., Golden, D. M., Hampson, R. F., Kurylo, M. J., Howard, C. J., Ravishankara, A. R., Kolb, C. E., and Molina, M. J.: Chemical kinetics and photochemical data for use in stratospheric modeling, Evaluation No. 12, Jet Propulsion Laboratory, Publication 97-4, Pasadena, CA, available at: http: //jpldataeval.jpl.nasa.gov/pdf/Atmos97_Anotated.pdf, 1997.

De Rooij, W. A. and Van der Stap, C. C. A. H.: Expansion of Mie scattering matrices in generalized spherical functions, Astron. Astrophys., 131, 237-248, 1984.

Dikty, S. and Richter, A.: GOME-2 on MetOp-A Support for Analysis of GOME-2 In-Orbit Degradation and Impacts on Level 2 Data Products, Final Report, version 2.0, available at: http://www.iup.uni-bremen.de/doas/reports/Final_ Report_Level-2_Data_GOME-2_Degradation.pdf, 2011.

EUMETSAT: AVHRR Level 1b Product Guide, Issue v3A, available at: http://www.eumetsat.int/website/home/Data/Products/ Level1Data/index.html, 2011.

Fontenla, J., White, O. R., Fox, P. A., Avrett, E. H., and Kurucz, R. L.: Calculation of solar irradiances. I. Synthesis of the solar spectrum, Astrophys. J., 518, 480-499, doi:10.1086/307258, 1999.

Grzegorski, M.: Polar Multi-Sensor Aerosol Product: ATBD, available at: http://www.eumetsat.int/website/home/Data/Products/ Atmosphere/index.html, 2014.

Hall, F. G., Brown de Colstoun, E., Collatz, G. J., Landis, D., Dirmeyer, P., Betts, A., Huffman, G. J., Bounoua, L., and Meeson, B.: ISLSCP Initiative II global data sets: surface boundary conditions and atmospheric forcings for landatmosphere studies, J. Geophys. Res.-Atmos., 111, D22S01, doi:10.1029/2006JD007366, 2006.

Han, W., Stamnes, K., and Lubin, D.: Remote sensing of surface and cloud properties in the Arctic from AVHRR measurements, J. Appl. Meteorol., 38, 989-1012, 1999.

Hao, N., Koukouli, M. E., Inness, A., Valks, P., Loyola, D. G., Zimmer, W., Balis, D. S., Zyrichidou, I., Van Roozendael, M., Lerot, C., and Spurr, R. J. D.: GOME-2 total ozone columns from MetOp-A/MetOp-B and assimilation in the MACC system, Atmos. Meas. Tech., 7, 2937-2951, doi:10.5194/amt-7-2937-2014, 2014.

Herman, J. R. and Celarier, E. A.: Earth surface reflectivity climatology at 340-380 nm from TOMS data, J. Geophys. Res.Atmos., 102, 28003-28011, 1997.

Holben, B. N., Tanré, D., Smirnov, A., Eck, T. F., Slutsker, I., Abuhassan, N., Newcomb, W. W., Schafer, J. S., Chatenet, B., Lavenu, F., Kaufman, Y. J., Castle, J. V., Setzer, A., Markham, B., Clark, D., Frouin, R., Halthore, R., Karneli, A., O’Neill, N. T., Pietras, C., Pinker, R. T., Voss, K., and Zibordi, G.: An emerging ground-based aerosol climatology: aerosol optical depth from AERONET, J. Geophys. Res.-Atmos., 106, 12067-12097, doi:10.1029/2001JD900014, 2001.

Holick, M. F.: Vitamin D deficiency, New Engl. J. Med., 357, 266281, doi:10.1056/NEJMra070553, 2007.

Kinne, S.: Towards an observation-tied AOD climatology, presentation in AT2 Aerosol Workshop, Bremen, 21-22 June, 2007.

Koelemeijer, R. B. A., de Haan, J. F., and Stammes, P.: A database of spectral surface reflectivity in the range $335-772 \mathrm{~nm}$ derived from 5.5 years of GOME observations, J. Geophys. Res.-Atmos., 108, 4070, doi:10.1029/2002JD002429, 2003.

Koepke, P., Hess, M., Schult, I., and Shettle, E. P.: Global Aerosol Data Set, Tech. Rep. 243, Max-Planck-Institut für Meteorologie, Hamburg, available at: http://rascin.net/sites/default/files/ downloads/MPI-Report_243.pdf, 1997.

Konzelmann, T., van de Wal, R. S., Greuell, W., Bintanja, R., Henneken, E. A., and Abe-Ouchi, A.: Parameterization of global and longwave incoming radiation for the Greenland Ice Sheet, Global Planet. Change, 9, 143-164, 1994.

Koukouli, M. E., Balis, D. S., Loyola, D., Valks, P., Zimmer, W., Hao, N., Lambert, J.-C., Van Roozendael, M., Lerot, C., and Spurr, R. J. D.: Geophysical validation and long-term consistency between GOME-2/MetOp-A total ozone column and measurements from the sensors GOME/ERS-2, SCIAMACHY/ENVISAT and OMI/Aura, Atmos. Meas. Tech., 5, 2169-2181, doi:10.5194/amt-5-2169-2012, 2012.

Krotkov, N. A., Bhartia, P. K., Herman, J. R., Fioletov, V., and Kerr, J.: Satellite estimation of spectral surface UV irradiance in the presence of tropospheric aerosols: 1 . Cloud-free case, J. Geophys. Res.-Atmos., 103, 8779-8793, 1998.

Krotkov, N. A., Herman, J. R., Bhartia, P. K., Fioletov, V., and Ahmad, Z.: Satellite estimation of spectral surface UV irradiance: 2. Effects of homogeneous clouds and snow, J. Geophys. Res.Atmos., 106, 11743-11759, 2001.

Kujanpää, J.: Algorithm Theoretical Basis Document: Offline UV (OUV) Products, SAF/O3M/FMI/ATBD/001, Issue 1.4, June 2013, available at: http://o3msaf.fmi.fi/docs/atbd/Algorithm Theoretical_Basis_Document_OUV_Jun_2013.pdf, 2013a.

Kujanpää, J.: Product User Manual: Offline UV (OUV) Products, SAF/O3M/FMI/PUM/001, Issue 1.5, June 2013, available at: http://o3msaf.fmi.fi/docs/pum/Product_User_Manual_OUV_ Jun_2013.pdf, 2013b.

Kurucz, R. L., Furenhild, I., Brault, J., and Testermann, L.: Solar flux atlas from 296 to $1300 \mathrm{~nm}$, National Solar Observatory Atlas No. 1, June 1984, 1984.

Lamberg-Allardt, C. J. E., Outila, T. A., Kärkkäinen, M. U. M., Rita, H. J., and Valsta, L. M.: Vitamin D deficiency and bone health in healthy adults in Finland: could this be a concern in other parts of Europe?, J. Bone Miner. Res., 16, 2066-2073, 2001.

Loyola, D.: Automatic cloud analysis from polar-orbiting satellites using neural network and data fusion techniques, in: Geoscience and Remote Sensing Symposium, 2004. IGARSS '04. Proceedings. 2004 IEEE International, vol. 4, doi:10.1109/IGARSS.2004.1369811, 2530-2533, 2004.

Loyola, D. and Ruppert, T.: A new PMD cloud-recognition algorithm for GOME, Earth Obs. Q., 58, 45-47, 1998.

Loyola, D. G., Thomas, W., Livschitz, Y., Ruppert, T., Albert, P., and Hollmann, R.: Cloud properties derived from GOME/ERS-2 backscatter data for trace gas retrieval, IEEE T. Geosci. Remote, 45, 2747-2758, 2007.

Loyola, D. G., Thomas, W., Spurr, R., and Mayer, B.: Global patterns in daytime cloud properties derived from GOME backscatter UV-VIS measurements, Int. J. Remote Sens., 31, 4295-4318, 2010.

Loyola, D. G., Koukouli, M. E., Valks, P., Balis, D. S., Hao, N., Van Roozendael, M., Spurr, R. J. D., Zimmer, W., Kiemle, S., Lerot, C., and Lambert, J.-C.: The GOME-2 to- 
tal column ozone product: Retrieval algorithm and groundbased validation, J. Geophys. Res.-Atmos., 116, D07302 doi:10.1029/2010JD014675, 2011.

Madronich, S.: Tropospheric photochemistry and its response to UV changes, in: The Role of the Stratosphere in Global Change, edited by: Chanin, M.-L., vol. 8 of NATO ASI Series, Springer, Berlin, Heidelberg, doi:10.1007/978-3-642-78306-7_22, 437461, 1993.

Mahesh, A., Walden, V. P., and Warren, S. G.: Ground-based infrared remote sensing of cloud properties over the Antarctic Plateau. Part II: Cloud optical depths and particle sizes, J. Appl. Meteorol., 40, 1279-1294, 2001.

Malicet, J., Daumont, D., Charbonnier, J., Parisse, C., Chakir, A., and Brion, J.: Ozone UV spectroscopy. II. Absorption crosssections and temperature dependence, J. Atmos. Chem., 21, 263 273, doi:10.1007/BF00696758, 1995.

Martin, T. J., Gardiner, B. G., and Seckmeyer, G.: Uncertainties in satellite-derived estimates of surface UV doses, J. Geophys. Res.-Atmos., 105, 27005-27011, doi:10.1029/2000JD900432, 2000.

McKinlay, A. F. and Diffey, B. L.: A reference action spectrum for ultraviolet induced erythema in human skin, CIE Research Note, 6, 1987.

McPeters, R. D. and Labow, G. J.: An assessment of the accuracy of 14.5 years of Nimbus 7 TOMS version 7 ozone data by comparison with the Dobson network, Geophys. Res. Lett., 23, 36953698, doi:10.1029/96GL03539, 1996.

McPeters, R. D., Bhartia, P. K., Krueger, A. J., Herman, J. R., Wellemeyer, C. G., Seftor, C. J., Jaross, G., Torres, O., Moy, L., Labow, G., Byerly, W., Taylor, S. L., Swissler, T., and Cebula, R. P.: Earth Probe Total Ozone Mapping Spectrometer (TOMS) Data Products User's Guide, NASA Goddard Space Flight Center, Greenbelt, MD, available at: http://ozoneaq.gsfc. nasa.gov/media/docs/epusrguide.pdf, 1998.

Meerkötter, R. and Bugliaro, L.: Synergetic use of NOAA/AVHRR and Meteosat cloud information for space-based UV measurements, in: Proc. SPIE, vol. 4482, San Diego, CA, USA, 29 July 2001, doi:10.1117/12.452915, 169-176, 2002.

Meerkötter, R., Verdebout, J., Bugliaro, L., Edvardsen, K., and Hansen, G.: An evaluation of cloud affected UV radiation from polar orbiting and geostationary satellites at high latitudes, Geophys. Res. Lett., 30, 1956, doi:10.1029/2003GL017850, 2003.

Mishchenko, M. I., Geogdzhayev, I. V., Cairns, B., Carlson, B. E., Chowdhary, J., Lacis, A. A., Liu, L., Rossow, W. B., and Travis, L. D.: Past, present, and future of global aerosol climatologies derived from satellite observations: a perspective, J. Quant. Spectrosc. Ra., 106, 325-347, doi:10.1016/j.jqsrt.2007.01.007, 2007.

Munro, R., Lang, R., Klaes, D., Poli, G., Retscher, C., Lindstrot, R., Huckle, R., Lacan, A., Grzegorski, M., Holdak, A., Kokhanovsky, A., Livschitz, J., and Eisinger, M.: The GOME2 instrument on the Metop series of satellites: instrument design, calibration, and level 1 data processing - an overview, Atmos. Meas. Tech. Discuss., 8, 8645-8700, doi:10.5194/amtd-8-86452015, 2015.

Robel, J. E.: NOAA KLM User's Guide with NOAA-N, -N' Supplement, National Environmental Satellite, Data, and Information Service, available at: http://www1.ncdc.noaa.gov/pub/data/ satellite/publications/podguides/N-15thruN-19/pdf/, 2014.
Schneider, W., Moortgat, G. K., Tyndall, G. S., and Burrows, J. P.: Absorption cross-sections of $\mathrm{NO}_{2}$ in the $\mathrm{UV}$ and visible region (200-700 nm) at 298 K, J. Photoch. Photobio. A, 40, 195-217, doi:10.1016/1010-6030(87)85001-3, 1987.

Schoeberl, M., Douglass, A., Hilsenrath, E., Bhartia, P., Beer, R., Waters, J., Gunson, M., Froidevaux, L., Gille, J., Barnett, J., Levelt, P., and DeCola, P.: Overview of the EOS aura mission, IEEE T. Geosci. Remote, 44, 1066-1074, doi:10.1109/TGRS.2005.861950, 2006.

Seckmeyer, G., Bais, A., Bernhard, G., Blumthaler, M., Eriksen, P., McKenzie, R. L., Roy, C., and Miyauchi, M.: Instruments to measure solar ultraviolet radiation, Part I: spectral instruments, WMO-GAW report No. 125 (WMO TD No. 1066), Geneva, Switzerland, 2001.

Setlow, R. B.: The wavelengths in sunlight effective in producing cancer: a theoretical analysis, P. Natl. Acad. Sci. USA, 71, 33633366, 1974.

Sinha, R. P. and Hader, D.-P.: UV-induced DNA damage and repair: a review, Photochem. Photobio. S., 1, 225-236, doi:10.1039/B201230H, 2002.

Spurr, R. J.: VLIDORT: A linearized pseudo-spherical vector discrete ordinate radiative transfer code for forward model and retrieval studies in multilayer multiple scattering media, J. Quant. Spectrosc. Ra., 102, 316-342, 2006.

Talukdar, R. K., Longfellow, C. A., Gilles, M. K., and Ravishankara, A. R.: Quantum yields of $\mathrm{O}\left({ }^{1} \mathrm{D}\right)$ in the photolysis of ozone between 289 and $329 \mathrm{~nm}$ as a function of temperature, Geophys. Res. Lett., 25, 143-146, doi:10.1029/97GL03354, 1998.

Tanskanen, A., Arola, A., and Kujanpää, J.: Lambertian surface albedo climatology at $360 \mathrm{~nm}$ from TOMS data using moving time-window technique, in: Proc. XX Quadrennial Ozone Symposium, Kos, Greece, 1-8 June 2004, 1159-1160, 2004.

Tanskanen, A., Krotkov, N., Herman, J., and Arola, A.: Surface ultraviolet irradiance from OMI, IEEE T. Geosci. Remote, 44, 1267-1271, doi:10.1109/TGRS.2005.862203, 2006.

Tanskanen, A., Lindfors, A., Määttä, A., Krotkov, N., Herman, J., Kaurola, J., Koskela, T., Lakkala, K., Fioletov, V., Bernhard, G., McKenzie, R., Kondo, Y., O’Neill, M., Slaper, H., den Outer, P., Bais, A. F., and Tamminen, J.: Validation of daily erythemal doses from Ozone Monitoring Instrument with ground-based UV measurement data, J. Geophys. Res.-Atmos., 112, D24S44, doi:10.1029/2007JD008830, 2007.

Tilstra, L. G., Tuinder, O. N. E., and Stammes, P.: GOME-2 surface LER product - Algorithm Theoretical Basis Document, KNMI Report O3MSAF/KNMI/ATBD/003, Issue 1.6, November 13, available at: http://o3msaf.fmi.fi/docs/atbd/Algorithm Theoretical_Basis_Document_LER_Nov_2014.pdf, 2014.

Van Roozendael, M., Loyola, D., Spurr, R., Balis, D., Lambert, J.C., Livschitz, Y., Valks, P., Ruppert, T., Kenter, P., Fayt, C., and Zehner, C.: Ten years of GOME/ERS-2 total ozone data - the new GOME data processor (GDP) version 4: 1. Algorithm description, J. Geophys. Res.-Atmos., 111, D14311, doi:10.1029/2005JD006375, 2006.

Verdebout, J.: A European satellite-derived UV climatology available for impact studies, Radiat. Prot. Dosim., 111, 407-411, doi:10.1093/rpd/nch063, 2004.

Wagner, R., Ajtai, T., Kandler, K., Lieke, K., Linke, C., Müller, T., Schnaiter, M., and Vragel, M.: Complex refractive in- 
dices of Saharan dust samples at visible and near UV wavelengths: a laboratory study, Atmos. Chem. Phys., 12, 2491-2512, doi:10.5194/acp-12-2491-2012, 2012.

Weatherhead, B., Tanskanen, A., and Stevermer, A.: Factors affecting surface ultraviolet radiation levels in the Arctic, in: Arctic Climate Impact Assessment, edited by: Symon, C., Cambridge University Press, New York, 2005.

Wellemeyer, C. G., Taylor, S. L., Seftor, C. J., McPeters, R. D., and Bhartia, P. K.: A correction for total ozone mapping spectrometer profile shape errors at high latitude, J. Geophys. Res.-Atmos., 102, 9029-9038, doi:10.1029/96JD03965, 1997.
WHO: Global Solar UV Index: a Practical Guide, available at: http: //www.who.int/uv/publications/en/UVIGuide.pdf, 2002.

Wu, X., Sullivan, J. T., and Heidinger, A. K.: Operational calibration of the Advanced Very High Resolution Radiometer (AVHRR) visible and near-infrared channels, Can. J. Remote Sens., 36, 602-616, doi:10.5589/m10-080, 2010.

Xiong, X., Lubin, D., Li, W., and Stamnes, K.: A critical examination of satellite cloud retrieval from AVHRR in the Arctic using SHEBA data, J. Appl. Meteorol., 41, 1195-1209, 2002. 